\title{
Correction to: “A. K. Mohanty: The Multilingual Reality: Living with Languages.” Psychol Stud (2020)
}

\author{
Shailaja Menon ${ }^{1}$ (D)
}

Published online: 16 May 2020

(C) National Academy of Psychology (NAOP) India 2020

\section{Correction to: Psychol Stud \\ https://doi.org/10.1007/s12646-020-00552-0}

It is regretted that the title of the Review paper has been published incorrectly in the online publication of the article. Since the book is not an edited volume, but a single author book, the correct title should read as "A. K. Mohanty: The Multilingual Reality: Living with Languages.”

Publisher's Note Springer Nature remains neutral with regard to jurisdictional claims in published maps and institutional affiliations.

The original article can be found online at https://doi.org/10.1007/s12646-020-00552-0.

Shailaja Menon

shailaja.menon@apu.edu.in

1 Azim Premji University, Bangalore, Karnataka, India 